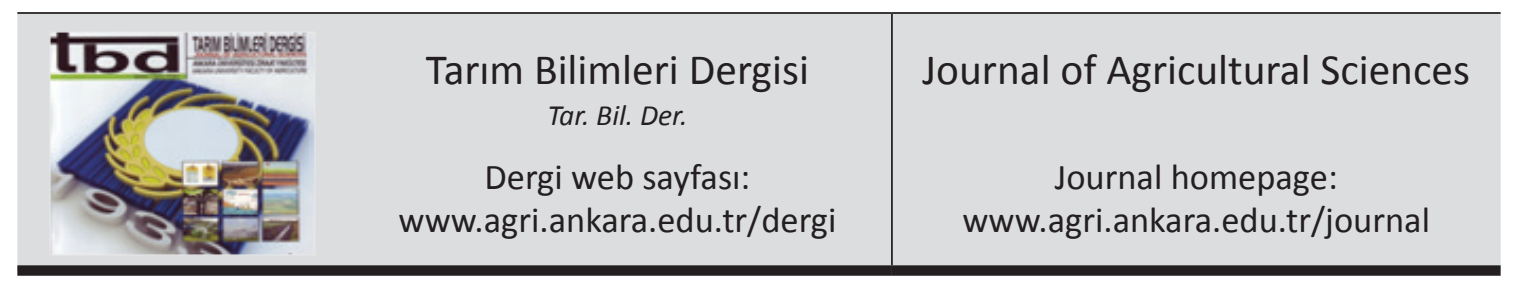

\title{
Farklı Kaplama Bileşenleriyle Kaplamanın Derin Yağda Kızartılan Piliç Nuggetların Bazı Kalite Karakteristikleri Üzerine Etkileri
}

\author{
Ramazan GÖKÇE ${ }^{a}$, Ali Aytaç AKGÜNª, Haluk ERGEZER ${ }^{a}$, Tolga AKCAN ${ }^{a}$ \\ ${ }^{a}$ Pamukkale Üniversitesi, Mühendislik Fakültesi, Glda Mühendisliği Bölümü, Denizli, TÜRKIYYE \\ ESER BILGİSI \\ Araştırma Makalesi \\ DOI: 10.1501/Tarimbil 0000001391 \\ Sorumlu Yazar: Haluk ERGEZER, E-posta: hergezer@pau.edu.tr, Tel: +90 (258) 2963339 \\ Geliş Tarihi: 27 Ekim 2014, Düzeltmelerin Gelişi: 11 Mart 2015, Kabul: 11 Mart 2015
}

\begin{abstract}
ÖZET
Bu çalışmada farklı tahıl ve baklagil unlarının (buğday, mısır, çavdar ve soya) derin yağda kızartılmış piliç nuggetların kalite karakteristikleri (nem miktarı, yağ miktarı, kaplama tutunma yüzdesi, pişirme verimi, kaplama kalınlığı, penetrometre değeri ve renk) üzerine etkileri incelenmiştir. Piliç nuggetlar eşit oranda but ve göğüs eti karışımından üretilmiş, ardından $180{ }^{\circ} \mathrm{C}^{\prime}$ ye 1 sıttılmış ayçiçek yağında 5 dakika süreyle derin yağda kızartılmıştır. Kaplama formülasyonları; piliç nuggetların kaplama tutunma yüzdesi, pişirme verimi, kaplama kalınlığı ve penetrometre değerlerini önemli $(\mathrm{P}<0.05)$ düzeyde etkilemiştir. En yüksek pişirme verimi sırasıyla mısır ve buğday unlu kaplamalarda elde edilmiştir. Çavdar unu kullanımı piliç nuggetların penetrometre değerini önemli $(\mathrm{P}<0.05)$ düzeyde artırmıştır. Piliç nuggetların nem miktarları kaplama formülasyonundan etkilenmezken, yağ miktarları değişiklik göstermiştir. Tüm kaplama formülasyonları kırmızılık $\left(+\mathrm{a}^{*}\right)$ değerleri açısından farklılık göstermezken $(\mathrm{P}>0.05)$ en yüksek sarılık $\left(+\mathrm{b}^{*}\right)$ değeri misır unlu kaplamalarda elde edilmiştir.

Anahtar Kelimeler: Piliç nugget; Sıvı kaplama; Kalite; Derin yağda kızartma; Pişirme verimi
\end{abstract}

\section{Effects of Different Batter Formulation on Some Quality Characteristics of Deep-Fat Fried Chicken Nuggets}

\author{
ARTICLE INFO \\ Research Article \\ Corresponding Author: Haluk ERGEZER, E-mail: hergezer@pau.edu.tr, Tel: +90 (258) 2963339 \\ Received: 27 October 2014, Received in Revised Form: 11 March 2015, Accepted: 11 March 2015
}

\begin{abstract}
In this study the effect of various cereal and legume flours (wheat, corn, rye and soy) on some quality characteristics (moisture content, oil content, coating pick up, cooking yield, coating thickness, penetrometer values and color) of deepfat fried chicken nuggets were studied. Chicken nuggets were prepared with equal amounts of ground thigh and breast meat and fried at $180^{\circ} \mathrm{C}$ for $5 \mathrm{~min}$ in sunflower oil. Batter formulations significantly $(\mathrm{P}<0.05)$ affected coating pick up, cooking yield, coating thickness and penetrometer values of chicken nuggets. The highest cooking yield was found in corn flour and wheat flour, respectively. The uses of rye flour significantly $(\mathrm{P}<0.05)$ increased the penetrometer values
\end{abstract}


of chicken nuggets. There were no significant $(\mathrm{P}>0.05)$ differences between the moisture content of chicken nuggets. The batter formulation significantly changed the oil content of chicken nuggets. All the batter formulations had similar redness $\left(+\mathrm{a}^{*}\right)$ values whereas batter containing corn flour showed the highest yellowness $\left(+\mathrm{b}^{*}\right)$ value.

Keywords: Chicken nugget; Batter; Quality; Deep fat frying; Cooking yield

(C) Ankara Üniversitesi Ziraat Fakültesi

\section{Giriş}

Tüm dünyada olduğu gibi ülkemizde de kanatlı etlerine ve bunlardan üretilen ürünlere olan talep giderek artmaktadır. Kanatlı etlerine talebi artıran faktörler arasında cazip fiyat, sağlıklı olma, kolay ulaşılabilirlik ve hazırlanabilirlik başta gelmektedir. Özellikle ileri işlenmiş kanatlı eti ürünleri katma değeri yüksek ürünler olup; kâr oranlarının yüksek olması nedeniyle üreticiler, ürün çeşitliliğinin fazla olması nedeniyle de tüketiciler tarafindan tercih edilmektedir. İleri işlenmiş ürünler içerisinde de kaplamalı ürünlere ilgi gün geçtikçe artmaktadır. Özellikle altın sarısı kaplama rengi, gevrekliği, ve lezzetli yapısı ile her daim sıcak olarak kısa sürede servis edilebilen kaplamalı ürünler, her yaştan tüketici için caziptir (Fiszman \& Sanz 2010).

Kaplanmış ürünler farklı kompozisyonlarda birkaç katmandan oluşan sandviç benzeri bir yapıya sahiptir. Dışta kuru, sıkı ve gevrek bir kabuk, içte ise yumuşak yapılı et tabakası bulunur. $\mathrm{Bu}$ yapının oluşmasında ürünün nem içeriği, et parçalarının büyüklügü̈, kaplama materyalinin bileşimi, pişirme işlemi, pişirme süresi ve sıcaklığ 1 büyük önem taşımaktadır (Albert et al 2014).

Kaplamalı kanatlı ürünlerin en çok tercih edileni piliç nuggetlardır. Üretim aşamasında piliç nuggetlar önce buğday, mısır unu, nişasta ve yumurta gibi katkılar bulunan sivı bir kaplamaya daldırılır, ardından tercihen galeta unlu bir kuru kaplamayla işlenir ve son olarak derin yağda belirli süre kizartılır (Suderman 1983; Fiszman \& Salvador 2003; Altunakar et al 2004; Albert et al 2009).

Kaplanmış ürünlerde kaplama materyalinin viskozitesi, adhezyon özelliklikleri (kaplamanın ürüne tutundurulması) ve kızartma sırasında yağ absorbsiyonunun azaltılması gibi kriterler kaplama bileşimiyle doğrudan ilişkilidir. Bunun yanı sıra kaplama bileşimi, son ürünün tekstür, renk ve lezzet gibi kalite kriterleri; pişirme sıcaklığ 1 , yöntemi ve süresini de etkilemektedir (Ergezer et al 2008). Farklı unların kaplama sistemleri üzerindeki etkileri pek çok araştırıcı tarafından incelenmiştir. Buğday unu içermiş olduğu gluten ve glutenin film oluşturucu özellikleri nedeniyle piliç nuggetlarda nem kaybını azaltıp, gevrekliği artırmaktadır. Buğday ununun yanı sıra pirinç, mısır ve soya unu da kaplama formülasyonlarında denenmiş ve başarılı sonuçlar alınmıştır (Suderman 1983; Fiszman \& Salvador 2003; Altunakar et al 2004; Ergezer et al 2008; Albert et al 2009; Fiszman \& Sanz 2010; Albert et al 2014).

Soya unu ile gerçekleştirilen kaplama çalışmalarında pirinç ununa kıyasla piliç nuggetlarda nem kaybının ve yağ absorbsiyonunun daha az olduğu, rengin iyileştiği ve gevrekliğin de arttığ1 belirlenmiştir (Altunakar et al 2004).

Misır unu, içermiş olduğu karoten pigmenti nedeniyle kaplanmış ürünlerde aranan altın sarısı renk için önemli ve doğal bir kaplama materyali olarak kullanılmaktadır. Ayrıca mısır unu bileşiminde bulunan zein proteini hidrofilik özelliği nedeniyle ürünün içerisinde suyun alıkonmasına yardımcı olmakta ve kızartma yağının da ürüne geçmesine engellemektedir. $\mathrm{Bu}$ nedenle son ürünün içi sulu ve dışı daha gevrek algilanmaktadır (Fiszman \& Sanz 2010).

$\mathrm{Bu}$ çalışmada, farklı kaplama bileşenlerinin derin yağda kızartılmış piliç nuggetların bazı kalite parametreleri üzerindeki etkileri incelenmiş̧ir.

\section{Materyal ve Yöntem}

\subsection{Materyal}

Çalı̧̧mada ticari bir tavuk kesimhanesinden temin edilmiş, kemiksiz ve derisiz but ve göğüs etleri kullanılmıştır. Kaplama ve piliç nugget formülasyonlarının hazırlanmasında kullanılan karragenan (Tunçkaya Kimya); peynir altı suyu tozu 
ve mono sodyum glutamat (AD Kimya); buğday, mısır, soya ve çavdar unları; galeta unu, karabiber, kimyon, soğan, tuz ve ayçiçek yağı piyasadan temin edilmiştir.

\subsection{Yöntem}

\subsubsection{Piliç nuggetların hazırlanışı}

Tavuk but ve gögüs etleri $5 \mathrm{~mm}$ ayna gözlü kıyma makinesinde (Arı Makine, PKM 12, Türkiye) çekilmiştir. Araştırmada Çizelge 1'de belirtilen piliç nugget formülasyonu kullanılarak elle yoğurmak suretiyle hamur hazırlanmıştır. Elips şeklindeki paslanmaz çelikten imal edilmiş kalıplar (1.5 x 5.5 x 4 $\mathrm{cm})$ kullanılarak hamur nugget formuna getirilmiştir.

Çalışmada kaplama bileşeni olarak \% 35 un (buğday, mısır, soya ve çavdar), \% 1 karragenan, $\% 1$ tuz ve \% 63 su kullanılarak 4 farklı kaplama grubu oluşturulmuştur.

Piliç nuggetlar hazırlanmış kaplama formülasyonlarına daldırılmadan önce daha etkin bir tutunma sağlamak amacıyla peynir altı suyu tozuyla ön unlamaya tabi tutulmuştur. Kaplama uygulamalarında Sıvı kaplama tercih edilmiş olup kaplama çözeltisi $45 \pm 1{ }^{\circ} \mathrm{C}$ 'deki su içerisinde 30 sn karıştırılarak hazırlanmıştır. Ön unlamanın ardından piliç nuggetlar bu kaplama çözeltisine 10 sn daldırılmak suretiyle kaplanarak kızartıcıya konulmuştur. Kaplanan piliç nuggetlar $180{ }^{\circ} \mathrm{C}$ 'ye ayarlanmış kızartıcıda (Tefal, Filtra One 1900 watt, Fransa) 5’er dakika ayçiçek yağı içerisinde kızartılmıştır (Altunakar 2003).

Çizelge 1- Çalışmada uygulanan nugget formülasyonu

Table 1- Formulation of chicken nuggets

\begin{tabular}{lc}
\hline Bileşen & Oran (\%) \\
\hline Tavuk kıyması (1:1; göğüs:but) & 82.5 \\
Galeta unu & 5 \\
Kimyon & 0.5 \\
Karabiber & 0.5 \\
Soğan & 10 \\
MSG (mono sodyum glutamat) & 0.5 \\
Tuz & 1 \\
\hline
\end{tabular}

\subsubsection{Analizler}

Pişmiş örneklerin nem miktarı etüvde (Memmert UNE400, Almanya) $105 \pm 2{ }^{\circ} \mathrm{C}$ 'de kurutma (AOAC 2000), yağ miktarı Soxhlet ekstraksiyonu yöntemine göre belirlenmiştir (AOAC 2000). Örneklerin renk değerleri kızartma sonrası (Hunter lab Miniscan XE Plus, ABD) renk ölçüm cihazı ile belirlenmiştir. CIELAB sistemi, D65 referans aydınlatma ve $10^{\circ}$ lik görüş açısında 4 ayrı okuma ile kuartz örnek kabı içerisinde yapılmıştır. Sonuçlar açıklık-koyuluk (L*), kırmızılık $\left(+\mathrm{a}^{*}\right)$ ve sarılık $\left(+b^{*}\right)$ değerleri kullanılarak saptanmıştır (CIE 2001).

Çiğ piliç nugget örneklerinde kaplama tutunma yüzdesi ve pişirme verimi Eşitlik 1 ve 2'de şu şekilde hesaplanmıştır (Altunakar 2003).

$\%$ Kaplama tutunma $=(\mathrm{C}-\mathrm{I} / \mathrm{I}) \times 100$

Burada; C, kaplanmış piliç nugget ağırlı̆̆ (g); I, kaplanmamış piliç nugget ağırlığı $(\mathrm{g})$.

\% Pişirme Verimi $=(\mathrm{CW} / \mathrm{C}) \times 100$

Burada; CW, pişmiş piliç nugget ağırlığı (g); C, çiğ piliç nugget ağırlığı $(\mathrm{g})$.

Kaplanan piliç nuggetlar kızartıldıktan sonra, kaplama bir bıçak yardımıyla sıyrılmış ve kaplamanın kalınlığg (mm) dijital kumpas (Mitutoyo CD-6 CSX, Japonya) ile belirlenmiştir.

Hazırlanan örneklerin sertlik değerinin belirlenmesi amaciyla penetrometre cihazı (Koehler, K95500 ABD) ile, 100 g ağırlığa sahip ve et ürünlerinde ölçüm için kullanılan konik başlık 3 farklı noktadan olmak üzere delme derinliği $10^{-1}$ $\mathrm{mm}$ cinsinden belirlenmiştir (Ergezer et al 2014).

\section{3. İstatistiksel analiz}

Elde edilen veriler 1şı̆̆ında sonuçlar ANOVA (Varyans Analizi) kullanılarak analiz edilmiştir. Sonuçlar Duncan Çoklu Karşılaştırma Testiyle değerlendirilmiş ve uygulama grupları arasında farklılık olup olmadığ 1 SPSS istatistik paket programı kullanılarak test edilmiştir (IBM SPSS 2012). 


\section{Bulgular ve Tartışma}

\subsection{Kalite karakteristiklerindeki değişimler}

Kaplamalı ürünlerde son ürün kalitesi üzerine etkili faktörlerden birisi kaplanacak ürüne kaplama materyalinin tutundurulma yüzdesidir. Kaplama formülasyonlarına ilave edilen protein içeriği yüksek unlarve değişik karakterdeki hidrokolloidlerkaplama tutunma yüzdesi üzerine etkilidir (Chen et al 2008). Farklı kaplama formülasyonlarına daldırılan çiğ piliç nuggetların kaplama tutunma yüzdesi \% 11.5314.28 arasında değişiklik göstermiş olup (Çizelge 2) örnekler arasındaki farklılık istatistiki olarak önemli bulunmuştur $(\mathrm{P}<0.05)$. En yüksek kaplama yüzdesine çavdar unu kullanılarak hazırlanan piliç nuggetlarda ulaşılmıştır. Buğday, soya ve pirinç ununun piliç nuggetlarda kaplama bileşeni olarak kullanıldığı bir çalışmada kaplama tutunma yüzdesi soya $>$ buğday $>$ pirinç unu şeklinde gerçekleşmiştir (Dogan et al 2005). Bu çalışmada kaplama tutunma yüzdesini artırmak amaciyla karragenan kullanılmıştır. Benzer bir çalışmada buğday ve mısır unu içeren kaplama formülasyonlarına farklı oranlarda ilave edilen gamların balık nuggetlarda kaplama tutunma yüzdesini önemli düzeyde artırdığı gözlenmiştir (Chen et al 2009). Ancak balık nuggetların kullanıldığı farklı bir çalışmada ise gam olarak kullanılan okside nişasta, ksantan gam ve hidroksipropil metil selülozun kaplama tutunma oranını artırmadığ 1 , aksine kontrol grubuna göre daha düşük değerler elde edildiği görülmüştür. $\mathrm{Bu}$ durumda asıl tutunmayı sağlayan yapının kaplama formülasyonuna ilave edilen undan kaynaklandığ 1 öne sürülmüştür (Albert et al 2009).
Pişirme verimi, pişirme sırasında kaplamanın yüzeye tutunabilme özelliğinin bir göstergesidir ve verim arttıkça ürünün ekonomik değeri de artmaktadır (Altunakar et al 2004). Örneklerin pişirilmesini takiben elde edilen verim sonuçlarına göre en yüksek değer misır unlu (\% 82.64) ve en düşük değer de soya unlu (\% 78.10) kaplamalarda bulunmuş ve örnekler arasında farklılık olduğu gözlenmiştir $(\mathrm{P}<0.05)$. Nişasta jelatinize olduğunda kaplanan yüzey üzerinde bir film oluşturmakta ve dolayısıyla da pişirme veriminde artışa neden olmaktadır. Hububat unlarından farklı olarak bir baklagil olan soyanın bileşiminde daha az nişasta bulunmaktadır ve dolayısıyla da soya unu kullanılarak kaplanan piliç nuggetlarda pişirme verimi düşük kalmıştır. Hububat unları ile kaplanmış piliç nuggetlarda ise verim açısından herhangi bir farklılık bulunmamıştır. Farklı nişasta tiplerinin piliç nuggetlarda kaplama verimi üzerine etkilerinin incelendiği bir çalışmada tapioka (veya tapyoka) nişastası buğday ve mısır nişastasına göre daha iyi sonuçlar vermiştir (Altunakar et al 2004).

Pişirme sonrası kaplama kalınlıkları incelendiğinde en kalın kaplamanın soyalı örneklerde olduğu $(1.28 \mathrm{~mm})$ ve örnekler arasında farklılık olduğu görülmüştür $(\mathrm{P}<0.05)$. Ancak buğday, mısır ve çavdar unu kullanılan örnekler arasında kalınlık açısından farklılık olmadığı tespit edilmiştir $(\mathrm{P}>0.05)$. Benzeri bir sonuca pişirme verimi değerlerinde de ulaşılmıştır. Bu çalışmada piliç nugget örneklerinde pişirmeden sonra soyalı olanların kaplama kalınlıklarının diğer örneklerden daha fazla bulunması, protein içeriği yüksek olan kaplamanın kızartma esnasındaki davranışı veya

\section{Çizelge 2- Nuggetlarda kalite karakteristikleri*}

Table 2- Quality characteristics of chicken nuggets

\begin{tabular}{lcccc}
\hline Örnek & $\begin{array}{c}\text { Kaplama tutunma } \\
\text { yüzdesi }(\%)\end{array}$ & $\begin{array}{c}\text { Pişirme verimi } \\
(\%)\end{array}$ & $\begin{array}{c}\text { Kaplama kalınlı̆̆ } \\
(\mathrm{mm})\end{array}$ & $\begin{array}{c}\text { Penetrometre değeri } \\
\left(10^{-1} \mathrm{~mm}\right)\end{array}$ \\
\hline Buğday & $11.53 \pm 0.58^{\mathrm{b}}$ & $82.34 \pm 2.21^{\mathrm{a}}$ & $1.17 \pm 0.09^{\mathrm{b}}$ & $65.77 \pm 1.38^{\mathrm{ab}}$ \\
Misır & $13.19 \pm 0.65^{\mathrm{a}}$ & $82.64 \pm 1.52^{\mathrm{a}}$ & $1.18 \pm 0.06^{\mathrm{b}}$ & $59.88 \pm 3.65^{\mathrm{b}}$ \\
Soya & $12.11 \pm 1.12^{\mathrm{ab}}$ & $78.10 \pm 1.02^{\mathrm{b}}$ & $1.28 \pm 0.14^{\mathrm{a}}$ & $53.25 \pm 2.92^{\mathrm{b}}$ \\
Çavdar & $14.28 \pm 1.43^{\mathrm{a}}$ & $81.91 \pm 1.46^{\mathrm{a}}$ & $1.15 \pm 0.12^{\mathrm{b}}$ & $73.62 \pm 3.43^{\mathrm{a}}$ \\
\hline
\end{tabular}

*, 2 tekrarlı analizlerin sonuçları ortalama \pm standart sapma şeklinde verilmiştir; a,b, aynı sütunda farklı harflerle işaretlenen ortalamalar arasındaki farklar önemlidir $(\mathrm{P}<0.05)$ 
kaplama materyalinin partikül büyüklüğü ile alakalı olduğu düşünülmektedir (Çizelge 2). Pişirme sırasında bazı kaplamalarda ortamdan buharlaşmayla uzaklaşacak su, yapı tarafindan tutulmakta ve bu durumda gözeneklilik artış gösterebilmektedir. Buna bağlı olarak da pişme işlemi sonrası kaplama

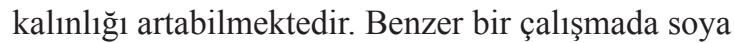
unu kullanılan kaplamalarda daha fazla gözenekli yapıya rastlanılmıştır (Dogan et al 2005).

Kaplanmış ürünlerde en önemli tekstürel özellik gevrekliktir. Gevreklik tüketici tercihlerinde ürünün taze olduğunun bir göstergesi olarak kabul edilmektedir (Ergezer et al 2008). Ürünün tekstürel özelliklerini belirlemek üzere kullanılan aletsel objektif analizlerden biri olan penetrometre değeri arttıkça ürünün daha yumuşak ve arzu edilir tekstürde olduğu söylenebilir (Candogan \& Kolsarici 2003). Penetrometre değerleri incelendiğinde tekstürel açıdan en yumuşak ürün çavdar unlu formülasyonla kaplanan piliç nuggetlarda elde edilmiştir. Soya ve misır unlu kaplamalarda ise penetrometre değeri benzer olup $(\mathrm{P}>0.05)$, çavdar ve buğday unlu kaplamalardan daha düşük değerler elde edilmiştir. $\mathrm{Bu}$ değerlere göre soya ve mısır unuyla kaplanmış örneklerin sertlik değerlerinin çavdar ve buğday unuyla kaplanmış örneklere göre daha yüksek olduğu söylenebilir. Örneklerin penetrometre değerleri $53.25-73.62 \times 10^{-1} \mathrm{~mm}$ arasında değişiklik göstermiş (Çizelge 2) ve örnekler arasında farklılık olduğu görülmüştür $(\mathrm{P}<0.05)$.

Üründe arzu edilen tekstürün sağlanabilmesi kaplama bileşenlerinin karakterine bağlıdır. Kaplama amaciyla kullanılan farklı karakterdeki unların, nişastaların ve gamların son ürün tekstürü üzerinde etkili olduğu pek çok araştırma tarafindan ortaya konmuştur (Mukprasirt et al 2000; Chen et al 2009). Sorgum ve buğday unlu piliç nuggetların karşılaştırıldığı bir çalışmada sorgum unu kullanılan örneklerin daha sert olduğu gözlemlenmiştir (Devatkal et al 2011). Bu çalışmaya benzer bir başka çalışmada ise buğday ve pirinç unu kullanılarak üretilen piliç nuggetlarda buğday unu kullanılan örneklerde daha yumuşak bir yapı elde edilmiştir (Jackson et al 2009). Yulaf ununun kaplama bileşeni olarak kullanıldığı başka bir çalışmada ise formülasyonda yulaf unu arttıkça sertliğin de arttığ1 belirlenmiştir (Santhi \& Kalaikannan 2014).

\subsection{Yağ ve nem miktarl}

Çizelge 3'te pişmiş örneklere ait yağ ve nem miktarları verilmiştir. Piliç nuggetların yağ miktarı \% 8.50-9.93 arasında değişiklik göstermekte ve örnekler arasında farklılık bulunmaktadır $(\mathrm{P}<0.05)$. Pişirme sırasında en az yağ çeken örnek misır unuyla kaplanan örnekler olmuştur. Örneklerin nem miktarları arasında herhangi bir farklılık tespit edilmemiştir $(\mathrm{P}>0.05)$.

Kaplanmış ürünlerin tüketimindeki en önemli problemlerden biri pişirme sırasında emilen yağ miktarıdır. Sağlık riskleri açısından bu tür ürünlerin kızartılması sırasında yağ absorbsiyonunun minimum düzeyde tutulması için pek çok çalışma yapılmaktadır. Kaplanmış ürünlerde pişirme koşulları (sıcaklık, süre), ön işlemler (ön unlama), gıdanın fiziko-kimyasal özelikleri, pişirmede kullanılan yağın kimyasal bileşimi ve kullanılan katkı maddelerinin özellikleri yağ absorbsiyonunu etkileyen önemli faktörler arasında yer almaktadır (Cuesta et al 2001; Rimac-Brnčić et al 2004; Dana \& Saguy 2006). Kaplamalı ürünlerde kullanılan değişik karakterli (nem, bileşen ve protein fonksiyonelliği) unlar ve bunların amiloz ve amilopektin içeriği son ürünün tekstürel karakteristikleri, yağ absorbsiyonu ve duyusal özellikleriyle çok iyi bir korelasyon göstermektedir (Fiszman \& Salvador 2003; Fiszman et al 2005; Fiszman \& Sanz 2010). Kaplamada kullanılan unda su, amilopektin veya protein oranının artması son üründe yağ absorbsiyonunu artırmakta ve gevreklik özelliğini azaltıcı yönde etki yapmaktadır. Bu çalışmada da benzer şekilde protein miktarı daha yüksek olan soya unlu gruplarda yă̆ içeriği diğer gruplara oranla daha yüksek bulunmuştur (Çizelge 3). Ancak başka bir çalışmada karideslerin kaplanmasında kullanılan soya ununun yağ absorbsiyonunu azalttığı, misır ununun ise artırdığı belirlenmiştir. Mısır unlu karideslerde yağ içeriğinin fazla bulunması bu undan hazırlanan sıvı kaplamalarda viskozitenin daha düşük kalması sonucu yağ absorbsiyonu için etkili bir bariyer oluşmamasına bağlanmaktadır (Nasiri et al 2012). 
Bilindiği üzere viskozitenin artırılması amaciyla değişik gamlar kaplama bileşenleri içerisine dâhil edilebilmektedir. $\mathrm{Bu}$ çalışmada da viskoziteyi artırabilmek amacıyla kullanılan karragenanın yağ absorbsiyonunu azalttığı düşünülmektedir.

Çizelge 3- Derin yağda kızartılmış nugget örneklerinde yağ ve nem miktarı*

Table 3-Oil and moisture content of deep fat fried chicken nugget samples

\begin{tabular}{lll}
\hline Örnek & $\begin{array}{l}\text { Yă̆ miktarl } \\
(\%)\end{array}$ & $\begin{array}{l}\text { Nem miktarl } \\
(\%)\end{array}$ \\
\hline Buğday & $8.96 \pm 0.18^{\mathrm{ab}}$ & $60.19 \pm 1.43^{\mathrm{a}}$ \\
Misır & $8.50 \pm 0.44^{\mathrm{b}}$ & $59.50 \pm 0.65^{\mathrm{a}}$ \\
Soya & $9.93 \pm 0.22^{\mathrm{a}}$ & $59.39 \pm 0.99^{\mathrm{a}}$ \\
Çavdar & $9.18 \pm 0.36^{\mathrm{ab}}$ & $61.40 \pm 1.05^{\mathrm{a}}$ \\
\hline
\end{tabular}

*, 2 tekrarlı analizlerin sonuçları ortalama \pm standart sapma şeklinde verilmiştir; ${ }^{a, b}$, aynı sütunda farklı harflerle işaretlenen ortalamalar arasındaki farklar önemlidir $(\mathrm{P}<0.05)$

Piliç nugget gibi kaplamalı ürünlerde aranan duyusal özelliklerden biri de sululuktur. Pişirme sırasında kaplama bileşenleri doğal bir bariyer görevi görerek etin bileşimindeki suyun dışarı çıkışını azaltır ve böylece ürünün sulu kalması sağlanır. Kaplama formülasyonlarına ilave edilen değişik karakterdeki tahıl ve bakliyat unlarının derin yağda kızartılmış ürünlerde nem miktarını etkilediği farklı araştırıcılar tarafindan belirtilmiştir (Fiszman \& Salvador 2003; Salvador et al 2005; Fiszman \& Sanz 2010). Ancak bu çalışmada piliç nuggetların nem miktarının kullanılan undan etkilenmediği gözlenmiştir. Derin yağda kızartma sırasında ortam sıcaklığının değişmesi nem miktarının değişmesine neden olmaktadır. Özellikle yă̆ sıcaklı̆̆ 1 arttıkça son üründe nem miktarının azaldığı bildirilmektedir (Nasiri et al 2012). Bu çalışmada kızartma ortamının sıcaklığının değişmemiş olmasının nem miktarının da değişmemesine neden olabileceği düşünülmektedir. Ayrıca çalışmada kullanılan hidrokolloid yapıdaki karragenanın da nemi tutmada etkili olduğu düşünülmektedir.

\subsection{Renk}

Pişmiş örneklerin renk değerleri Çizelge 4'te verilmiştir. Piliç nuggetların açıklık-koyuluk (L*) değerleri 28.79-39.16 arasında değişmiş ve örneklerin birbirinden farklı olduğu görülmüştür $(\mathrm{P}<0.05)$. En açık örneğin buğday kaplı, en koyu örneğin ise soya kaplı piliç nuggetlar olduğu görülmektedir. Piliç nuggetların kırmızılık değerleri $\left(+a^{*}\right)$ arasında istatistiksel olarak farklılık tespit edilememiştir $(\mathrm{P}>0.05)$. Piliç nuggetların albenisini ortaya koyan altın sarısı renk $\left(+b^{*}\right)$ bu çalışmada en iyi mısır unu ile kaplanmış örneklerde (18.88) tespit edilmiştir. Mısır ununa yakın özellikler sergileyen örnekler buğday unlu kaplamalarda saptanırken, soya unuyla kaplananların açıklık-koyuluk ve sarılık açısından en düşük değerlere sahip olduğu gözlenmiştir.

\section{Çizelge 4- Derin yağda kızartılmış nugget örneklerine ait renk değerleri*}

Table 4-Color values of deep fat fried chicken nuggets

\begin{tabular}{llll}
\hline Örnek & $L^{*}$ & $a^{*}$ & $b^{*}$ \\
\hline Buğday & $39.16 \pm 1.60^{\mathrm{a}}$ & $11.93 \pm 0.67^{\mathrm{a}}$ & $16.57 \pm 1.78^{\mathrm{a}}$ \\
Misır & $37.67 \pm 1.35^{\mathrm{a}}$ & $12.37 \pm 0.88^{\mathrm{a}}$ & $18.88 \pm 0.27^{\mathrm{a}}$ \\
Soya & $28.79 \pm 2.27^{\mathrm{b}}$ & $11.96 \pm 0.46^{\mathrm{a}}$ & $13.11 \pm 1.05^{\mathrm{b}}$ \\
Çavdar & $30.00 \pm 1.31^{\mathrm{b}}$ & $12.01 \pm 0.41^{\mathrm{a}}$ & $14.05 \pm 0.15^{\mathrm{ab}}$ \\
\hline *, 2 tekrarlı analizlerin sonuçları ortalama \pm standart sapma \\
şeklinde verilmiştir; a,b, aynı sütunda farklı harflerle işaretlenen \\
ortalamalar arasındaki farklar önemlidir $(\mathrm{P}<0.05)$
\end{tabular}

Kaplanmış ürünlerde tüketici beğenisinde önemli kalite karakteristiklerinden biri de renktir. $\mathrm{Bu}$ tür ürünlerde arzu edilen renk altın sarısıdır. Üründe istenen renk daha çok pişirmeyle ortaya çıtı̆̆ 1 için pişirme yöntemi, kızartma yağının sıcaklığı, çeşidi, kullanım süresi ya da sıklığ 1 ve kaplama materyalinin bileşimi büyük önem taşımaktadır (Ballard 2003). Renk stabilitesinin sağlanabilmesi için kızartma sırasında oluşan sıcaklık profili sürekli izlenmelidir. Kaplanmış ürünün soğuk veya aşırı sıcak yağın içine atılmaması gereklidir. Bununla birlikte ürünün kızartıcıda kalma süresi renk stabilitesi açısından çok önemlidir. Yine kızartma için kullanılan bitkisel yağın çeşidi ve durumu da renk açısından önemlidir. Kullanılacak kızartma yağının dumanlanma noktası yüksek olmalı, hidrolize veya polimerize olmuş yağlar kullanılmamalıdır. Yağa gıdadan geçen organik kirlilikler sık sık temizlenmelidir. 
Kaplama bileşiminde kullanılan katkı maddelerinin de renk üzerinde önemli etkisi bulunmaktadır (Fiszman et al 2005). Altın sarıs1 rengin sağlanabilmesi için mısır ununun kullanımı oldukça yaygındır. $\mathrm{Bu}$ çalışmada kızartma sıcaklığı, süresi, kullanılan yağ sabit tutulmuş sadece kaplama bileşenleri değiştirilmiştir. Çalışmada en koyu renk soya unu ile kaplanmış piliç nuggetlarda elde edilmiştir (Çizelge 4). $\mathrm{Bu}$ durumun soyanın protein miktarının tahıl unlarına göre daha fazla olması nedeniyle kızartma sırasında Maillard reaksiyonlarına daha fazla girme eğiliminden kaynaklanmış olabileceği düşünülmektedir. Piliç nugget örneklerinde en açık değer buğday unlu kaplamalarda elde edilmiş olup örneklerin kırmızılık değerleri kullanılan kaplama bileşenlerinden etkilenmemiştir. Nugget benzeri kaplanmış ürünlerde en önemli renk parametresi sarılık olup mısır unu ile kaplanmış örnekler bu açıdan en çok tercih edilen örnekler olmuştur. Mısır unlu örnekleri takiben sarılık değerleri sırasıyla buğday>çavdar>soya şeklinde gerçekleşmiştir. Benzer sonuçlar farklı araştırıcılar tarafından da ortaya konmuştur (Baixauli et al 2003; Fiszman et al 2005; Chen et al 2009).

\section{Sonuçlar}

Kanatlı etlerinde tüketimi artırmanın etkili yollarından biri nugget tipi kaplanmış ürünlerdir. Kaplama formülasyonları hazırlanırken standart buğday unlu kaplamalar yerine farklı tahıl ve baklagil unlarının da kullanımıyla daha lezzetli, gevrek, sulu ve besleyici değeri yüksek ürünlerin üretilmesi mümkün olabilecektir. $\mathrm{Bu}$ çalışmada elde edilen tüm parametreler göz önünde bulundurulduğunda kaplama formülasyonlarına misır ve çavdar unu ilavesinin ürün üzerinde olumlu etkilerde bulunduğu ancak soya unu ile kaplanan piliç nuggetlarda ise aynı düzeyde olumlu etkiye ulaşılamadığı belirlenmiştir.

\begin{tabular}{|ll|}
\hline \multicolumn{2}{|l|}{ Kisaltmalar ve Semboller } \\
\hline$L^{*}$ & Açılık-koyuluk \\
$+a^{*}$ & Kirmızılık \\
$+b^{*}$ & Sarılik \\
$M S G$ & Mono sodyum glutamat \\
\hline
\end{tabular}

\section{Kaynaklar}

Albert A, Perez-Munuera L, Quiles A, Salvador A, Fiszman S M \& Hernando L (2009). Adhesion in fried battered nuggets: Performance of different hydrocolloids as predusts using three cooking procedures. Food Hydrocolloids 23: 1443-1448

Albert A, Salvador A, Hough G \& Fiszman S (2014). Influence of outer layer formulation on the sensory properties of microwaved breaded nuggets. International Journal of Food Properties 17: 829-841

Altunakar B (2003). Functionally of different batters in deep-fat fried chicken nuggets. MSc., Middle East Technical University (Unpublished), Ankara

Altunakar B, Sahin S \& Sumnu G (2004). Functionality of batters containing different starch types for deep-fat frying of chicken nuggets. European Food Research and Technology 218: 318-322

AOAC (2000). Official methods of analysis of aoac international. In Association of Official Analysis Chemists International

Baixauli R, Sanz T, Salvador A \& Fiszman S M (2003). Effect of the addition of dextrin or dried egg on the rheological and textural properties of batters for fried foods. Food Hydrocolloids 17: 305-310

Ballard T (2003). Application of edible coatings in maintaining crispness of breaded fried foods. Master Thesis, Virginia Polytechnic Institute (Unpublished), USA

Candogan K \& Kolsarici N (2003). The effects of carrageenan and pectin on some quality characteristics of low-fat beef frankfurters. Meat Science 64(2): 199206

Chen H, Kang H \& Chen S (2008). The effects of ingredients and water content on the rheological properties of batters and physical properties of crusts in fried foods. Journal of Food Engineering 88: 45-54

Chen S, Chen H, Chao Y \& Lin R (2009). Effect of batter formula on qualities of deep-fat and microwave fried fish nuggets. Journal of Food Engineering 95: 359364

CIE (2001). Improvement to industrial colour-difference evaluation. In. Vienna: CIE Central Bureau

Cuesta C, Romero A \& Sánchez-Muniz F (2001). Fatty acid changes in high oleic acid sunflower oil during successive deep-fat fryings of frozen foods. Food Science and Technology International 7(4): 317-328 
Dana D \& Saguy I S (2006). Review: Mechanism of oil uptake during deep-fat frying and the surfactant effect-theory and myth. Advances in Colloid and Interface Science 128: 267-272

Devatkal S K, Kadam D M, Naik P K \& Sahoo J (2011). Quality characteristics of gluten-free chicken nuggets extended with sorghum flour. Journal of Food Quality 34: $88-92$

Dogan S F, Sahin S \& Sumnu G (2005). Effects of soy and rice flour addition on batter rheology and quality of deep-fat fried chicken nuggets. Journal of Food Engineering 71: 127-132

Ergezer H, Yıldız-Turp G \& Serdaroğlu M (2008). Su ürünleri kaplama yöntemleri ve karşılaşılan sorunlar. Akademik Gida 6(1): 11-16

Ergezer H, Akcan T \& Serdaroglu M (2014). The effects of potato puree and bread crumbs on some quality characteristics of low fat meatballs. Korean Journal for Food Science of Animal Resources 34(5): 561-569

Fiszman S \& Salvador A (2003). Recent developments in coating batters. Trends in Food Science \& Technology 14: 399-407

Fiszman S \& Sanz T (2010). Battering and Breading: Principles and System Development. Handbook of Poultry Science and Technology, Secondary Processing, John Wiley \& Sons, Inc. pp. 560

Fiszman S, Salvador A \& Sanz T (2005). Why, when and how hydrocolloids are employed in battercoated food-a review. Progress in Food Biopolymer Research 1: 55-68
IBM SPSS (2012). Ibm software business analytics. In (21 ed.)

Jackson V, Schilling M W, Falkenberg S M, Schmidt T B, Coggins P C \& Martin J M (2009). Quality characteristics and storage stability of baked and fried chicken nuggets formulated with wheat and rice flour. Journal of Food Quality 32: 760-774

Mukprasirt A, Herald T J, Boyle D L \& Rausch K D (2000). Adhesion of rice flour-based batter to chicken drumsticks evaluated by laser scanning confocal microscopy and texture analysis. Poultry Science 79: 1356-1363

Nasiri F D, Mohebbi M, Yazdi F T \& Khodaparast M H H (2012). Effects of soy and corn flour addition on batter rheology and quality of deep fat-fried shrimp nuggets. Food and Bioprocess Technology 5(4): 1238-1245

Rimac-Brnčić S, Lelas V, Rade D \& Šimundić B (2004). Decreasing of oil absorption in potato strips during deep fat frying. Journal of Food Engineering 64(2): 237-241

Salvador A, Sanz T \& Fiszman S (2005). Effect of the addition of different ingredients on the characteristics of a batter coating for fried seafood prepared without a pre-frying step. Food Hydrocolloids 19: 703-708

Santhi D \& Kalaikannan A (2014). The effect of the addition of oat flour in low-fat chicken nuggets. Journal of Nutrition \& Food Science 4: 260. doi: $10.4172 / 2155-9600.1000260$

Suderman D R (1983). Use of batters and breadings on food products: A review, in: D.R. Suderman, \& F. Cunningham (Eds.), Batter and breading, Westport: Avi Publishing Company, pp. 2 